\title{
Editorial
}

\section{DRUG COMPLIANCE IN THE TREATMENT OF LEPROSY*}

Recent publications in this journal concerning the regularity with which leprosy patients self-administer their dapsone treatment ${ }^{1-3}$ and of improved techniques for monitoring dapsone compliance ${ }^{4-7}$ make this an appropriate time to review the findings of previous investigations concerning the regularity of dapsone self-administration and to discuss their implications for the strategy of leprosy treatment.

Investigations concerning the regularity of self-administration in the treatment of other diseases indicates that poor compliance is an extremely widespread phenomenon. ${ }^{8-13}$ Extensive studies of compliance of tuberculosis patients have been carried out in several Third World countries in situations where leprosy is also endemic using simple colorimetric urine-tests to monitor the ingestion of isoniazid. ${ }^{14-19}$ In two of these studies ${ }^{17}, 18$ significant correlations were demonstrated between irregularity in drug self-administration, as indicated by the proportion of urine samples giving negative tests, and inadequate therapeutic response. Investigations in India ${ }^{20}$ and East Africa ${ }^{21-23}$ have also demonstrated that regimens that are highly effective when used in controlled clinical trials are often much less effective in routine use, primarily because patients do not continue with their treatment for an adequate length of time. Such evidence concerning the prevalence and therapeutic importance of poor compliance provided the impetus for initiating controlled clinical trials to investigate the efficacy of supervised intermittent regimens and of shortcourse chemotherapy in the treatment of pulmonary tuberculosis. ${ }^{24-6}$

\section{The dapsone/creatinine ratio method for monitoring the ingestion of dapsone}

The most satisfactory method of monitoring patient compliance is by means of simple procedures to specifically detect the prescribed drugs or their metabolites

*Based in part on papers presented to the Workshop on Experimental Chemotherapy, 11 th International Congress of Leprosy, Mexico City, November 1978; the Third THELEP Drug Development Subgroup Meeting, Geneva, April 1980; and the Third THELEP Scientific Working Group Meeting, Geneva, October 1980.

0305-7518/81/052201+ $13 \$ 01.00$ ㄷ British Leprosy Relief Association 
in the urine. Since dapsone, and most other antileprosy drugs are prescribed for daily self-administration, a highly satisfactory urine-test procedure would be one that gave reliably positive results for up to $12-15 \mathrm{~h}$ after the ingestion of a standard daily dose of the drug and consistently negative results within $48 \mathrm{~h}$. With such a test, a negative result would indicate unequivocally that a patient has omitted to ingest at least one of his or her prescribed doses.

Two factors frustrate efforts to devise such a simple test to monitor dapsone self-administration. Firstly, dapsone and its metabolites are eliminated very slowly in the urine at rates that parallel the decline in dapsone serum concentrations. ${ }^{27}$ This decline is equivalent on average to a half-life of about $27 \mathrm{~h}^{28}$ Secondly, colorimetric procedures for detecting dapsone are unspecific. Thus the most satisfactory colorimetric method for estimating dapsone, in which its aromatic amino groups are diazotized and coupled with N-1-naphthyl-ethylenediamine, gives colours with a wide range of other compounds containing aromatic amino groups.

For these reasons qualitative urine-tests give positive results for several days after the ingestion of a single therapeutic dose of dapsone and attempts to read tests in such a way as to avoid classifying concentrated dapsone-f ree urine samples with substantial amounts of natural diazotisable compounds as positive are liable to result in categorizing dilute dapsone-containing samples as negative. $^{29}$ The effects of diuresis can, however, be largely overcome by quantitatively determining the ratio of the concentration of dapsone plus its diazotisable metabolites to creatinine in the urine using modifications of the Bratton and Marshall and alkaline picrate colorimetric methods, respectively. ${ }^{27,} 29,30$ Urine samples can be conveniently preserved by the addition of hydrochloric acid or thymol and do not need to be refrigerated.

Studies of dapsone compliance using this method have been reported from Malawi, Ethiopia, India, Burma, Tanzania and Kenya. ${ }^{1-3}$, 30-8 Most outpatients are prescribed dapsone for daily self-administration. Estimates of their compliance were obtained by comparing the dapsone/creatinine ratios of urine samples collected during their visit to a rural, urban or hospital clinic with those of samples from supervised and non-treated controls, respectively. The samples from the supervised controls were generally collected from hospitalized patients $24 \mathrm{~h}$ after they had swallowed at least 4 consecutive supervised daily doses of dapsone of the same denomination as that given to the outpatients. The results of such investigations are summarized in Table 1 and indicate that irregular self-administration of dapsone is very widespread. In every study the dapsone/creatinine ratios of urine samples collected from the outpatients were significantly less than those from the supervised controls indicating that substantial proportions of the dapsone treatment prescribed for and collected by the outpatients were not being ingested. The overall level of self-medication as indicated by the mean dapsone/creatinine ratio of urine samples collected from outpatients could be interpreted in two ways. Firstly, if it is assumed that 
the pattern of dapsone ingestion immediately prior to collection of the urine samples is typical of the patients' general compliance, the approximate percentage of prescribed dapsone doses being ingested can be calculated. ${ }^{30}$ Such estimates calculated from the results obtained in investigations carried out in Malawi, Ethiopia, India and Burma are summarized in Table 1. Alternatively, the data can be analysed to provide an approximate estimate of the average length of time since patients had swallowed their last dose of dapsone. ${ }^{1}$

Table 1. Investigations of compliance using the dapsone/creatinine ratio method among outpatients prescribed dapsone for daily self-administration

\begin{tabular}{lccccc}
\hline \multicolumn{1}{c}{ Investigation } & & \multicolumn{3}{c}{$\begin{array}{c}\text { Grossly } \\
\text { irregular } \\
\text { Doses } \\
\text { patients** } \\
(\%)\end{array}$} & $\begin{array}{c}\text { Reference } \\
\text { taken** } \\
\text { (\%) }\end{array}$ \\
\hline Blantyre, Malawi (1974) & $\mathrm{R}$ & 164 & 53 & 30 & 30 \\
Addis Ababa, Ethiopia (1974) & $\mathrm{U}$ & 89 & 42 & 11 & 31 \\
Gudiyatham Taluk, India (1976) & $\mathrm{R}$ & 100 & 87 & 11 & 32 \\
Chinglepattu, India (1977) & $\mathrm{R}$ & 90 & 59 & - & 33 \\
Mandalay and Rangoon, & $\mathrm{H}$ & 170 & 74 & 24 & 34 \\
$\quad$ Burma (1979) & $\mathrm{U}$ and R & 455 & 24 & 56 & 35 \\
Bombay, India (1979) & $\mathrm{U}$ & 260 & - & 27 & 1 \\
Gudiyatham Taluk, India (1981) & $\mathrm{R}$ & 125 & 60 & 37 & 2 \\
Mazuffarpur, India (1981) & $\mathrm{R}$ & 44 & - & 25 & 36 \\
Dichpalli, India (1981) & $\mathrm{R}$ & 55 & 34 & 47 & 3 \\
Addis Ababa, Ethiopia (1981) & $\mathrm{U}$ & 368 & 78 & 11 & \\
\hline
\end{tabular}

* $\mathrm{R}=$ Rural, $\mathrm{U}=$ Urban, $\mathrm{H}=$ Hospital.

$* *$ For definitions see text.

The dapsone/creatinine ratios of many patients were clearly much less than those of the supervised controls and various definitions have been proposed for categorizing patients as being either 'irregular' or 'grossly irregular' in their dapsone self-administration. The proportions of patients classified as grossly irregular in Table 1 are those with apparent dapsone/creatinine ratios within the range found among samples from control subjects not receiving dapsone and varied from $11-56 \%$ of those studied. Such grossly irregular patients had probably not swallowed a tablet of dapsone for at least 4 days prior to the collection of the test urine sample. The question as to whether urine samples that have been collected from patients on the occasion of a visit to a clinic to replenish their stock of dapsone tablets are likely to be representative has been discussed previously. ${ }^{30}$ Interestingly, in the one study where urine samples were collected by means of both surprise home visits and during routine clinic attendances, significant differences were not encountered between the results from the two sets of samples. ${ }^{1}$ 


\section{Therapeutic implications of poor dapsone compliance}

Substantial failure to self-administer prescribed dapsone-treatment results not only from patients failing to ingest the tablets that they have collected but also because a substantial proportion of patients default from treatment altogether. ${ }^{39,40}$ Thus a recent study from South India has shown that after their first year's treatment many lepromatous patients become increasingly irregular in collecting their drug supplies and in self-administering dapsone and that such poor compliance may account for the failure of many patients to achieve clinical and bacteriological quiescence despite prolonged periods of dapsone monotherapy. ${ }^{36}$ However, because a single dose of $100 \mathrm{mg}$ dapsone results in serum and tissue drug concentrations that are approximately 500 -fold in excess of its minimal inhibitory concentration against Mycobacterium leprae and since the relatively long half-life of dapsone is such that inhibitory concentrations of the drug are probably maintained for about 10 days, ${ }^{28}$ it is clear that the failure to self-administer dapsone must be extremely prolonged before it results in clinical and bacteriological relapse caused by the renewed multiplication of fully dapsone-sensitive $M$. leprae. Such a conclusion is strengthened by the observation that over the short term the response of a small group of patients treated with a dose of $1 \mathrm{mg}$ dapsone/day was indistinguishable from that routinely observed with standard 50 or $100 \mathrm{mg}$ daily doses. ${ }^{41}$

The most important therapeutic penalty of poor dapsone compliance is likely to be an enhanced risk that lepromatous patients will relapse after many years of treatment due to the emergence of dapsone-resistant strains of $M$. leprae. It is extremely difficult to prove an association between poor compliance and relapse with dapsone-resistant leprosy many years later because records of out-patient treatment attendance are rarely well documented over long periods and urine-testing to monitor dapsone ingestion has only been introduced relatively recently. Nevertheless, Shepard and his colleagues obtained strongly suggestive evi.ence indicating that irregular treatment with dapsone is likely to be a major factor encouraging the development of dapsone resistance, ${ }^{42}$ while Jacobson reached a similar conclusion from his review of the case histories of over 75 patients with dapsone-resistant leprosy found over a 12-year period at the Carville United States Public Health Service Hospital. ${ }^{43}$ Other evidence for the importance of maintaining high concentrations of dapsone to prevent the subsequent emergence of dapsone resistance comes from studies concerning the epidemiology of dapsone resistance in Malaysia and Ethiopia. In the Malaysian investigation it was found that lepromatous inpatients whose treatment was initiated with injections of solapsone (equivalent to approximately $10 \mathrm{mg}$ dapsone/day) were three times more likely to relapse with dapsone-resistant leprosy than those whose treatment started with dapsone in full dosage. ${ }^{44}$ In Ethiopia, where standard treatment during the period 1965-74 for outpatients consisted of weekly doses of 
Table 2. Decline in the antileprosy activity of a $100 \mathrm{mg}$ dapsone dose with time

\begin{tabular}{|c|c|c|c|c|c|}
\hline \multirow[b]{2}{*}{ Days } & \multicolumn{2}{|c|}{ Dapsone serum concentration } & \multicolumn{3}{|c|}{ Inhibition M. leprae } \\
\hline & (\% initial) & $(\mu \mathrm{g} / \mathrm{ml})$ & $\mathrm{S}^{*}$ & low $\mathrm{R}^{* *}$ & medium $\mathrm{R}^{\dagger}$ \\
\hline 2 & 29 & 0.44 & + & + & \pm \\
\hline 3 & 16 & 0.24 & + & + & - \\
\hline 4 & 8.5 & 0.13 & + & + & - \\
\hline 5 & 4.5 & 0.07 & + & + & - \\
\hline 6 & 2.5 & 0.04 & + & \pm & - \\
\hline 7 & 1.5 & 0.02 & + & - & - \\
\hline 10 & 0.2 & 0.003 & \pm & - & - \\
\hline
\end{tabular}

5 or $10 \mathrm{mg}$ dapsone that were gradually increased to a maximum of $200-300 \mathrm{mg}$ over 6-9 months, ${ }^{45}$ the incidence of acquired dapsone resistance was alarmingly high (about 3\% per annum) and resistance to dapsone developed more rapidly than in Malaysia. ${ }^{46}$

Standard doses of 50 or $100 \mathrm{mg}$ dapsone taken regularly each day should not only completely prevent the growth of fully sensitive organisms but also that of mutants with low degrees of dapsone resistance, ${ }^{47}$ while substantial interruption of treatment will permit such mutants to multiply. Repeated interruptions of treatment over many years can therefore be expected to result in the step-wise selection of mutants with increasing levels of dapsone resistance until organisms are completely insusceptible to inhibition by the highest tolerated dapsone doses. The bacteriological and pharmacological basis for such selection is set out in Table 2. In constructing this table it has been assumed that a single dose of $100 \mathrm{mg}$ dapsone results in peak serum concentration of about $1.5 \mu \mathrm{g} / \mathrm{ml}$, that serum and tissue dapsone concentrations then decline at a rate equivalent to a half-life of $27 \mathrm{~h}$ and that the minimal inhibitory concentration of dapsone against fully sensitive strains of $M$. leprae is about $0.003 \mu \mathrm{g} / \mathrm{ml}$. The evidence for these assumptions and for the excellent tissue penetration of dapsone have been reviewed elsewhere. ${ }^{28,48}$ It will thus be apparent that if patients are prescribed $100 \mathrm{mg}$ dapsone for daily self-administration, mutants with low degrees of resistance (minimal inhibitory concentration of about $0.03 \mu \mathrm{g} / \mathrm{ml}$ ) might start to multiply after the omission of about 6 consecutive daily doses.

\section{More sensitive methods for monitoring dapsone compliance}

While the dapsone/creatinine ratio method has demonstrated the ubiquity of the failure of patients to take their prescribed dapsone treatment, the lack of 
specificity of the Bratton and Marshall procedure for detecting dapsone and its metabolites, exemplified by the significant blank values of urine samples from untreated subjects, results in the method being insufficiently sensitive to identify omissions of more than about 4 days treatment. However, as indicated by the data set out in Table 2, it is probable that significant therapeutic penalties are likely to be incurred in the long run only when gaps in dapsone self-administration of 6 days or more occur. By this time dapsone serum and tissue concentrations and urinary excretion will have fallen to about $1-2 \%$ of that encountered if the prescribed treatment were being regularly ingested. There is therefore a need for more sensitive and specific assay methods to detect dapsone and its metabolites in the urine.

After a single dose of $100 \mathrm{mg}$ dapsone, urinary concentrations of dapsone in excess of about $0.02 \mu \mathrm{g} / \mathrm{ml}$ are maintained for 7 days. ${ }^{49} \mathrm{High}$ pressure liquid chromatographic or thin layer chromatographic techniques of this order of sensitivity have been developed by several groups of workers, ${ }^{50-3}$ but none of these methods is simple enough for ready application to comprehensive studies of dapsone compliance. It is for this reason that the pioneering investigations of Huikeshoven and his colleagues ${ }^{4,5-6}$ to develop simple enzyme-immunoassays of great sensitivity and specificity for detecting dapsone and its metabolites in body fluids are of such promise.

In the first of their two 'ELISA' (Enzyme-linked immunosorbent assay) methods, ${ }^{4}$ aliquots of test urine samples and a solution containing a dapsonespecific immunoglobulin coupled to horseradish peroxidase are pipetted into the wells of a microtitre plate coated with a bovine serum albumin dapsone conjugate. After a washing step, the bound peroxidase is visualized using hydrogen peroxidase and 5-amino-salicylic acid, the amount of colour being inversely related to the concentration of dapsone and its metabolites in the test sample. When read by eye the method was capable of detecting concentrations of down to about $0.01 \mu \mathrm{g} / \mathrm{ml}$ dapsone in urine and gave reliably positive results when applied to urine samples collected from 9 of 10 volunteers for 8 days after the ingestion of single doses of $100 \mathrm{mg}$ dapsone.

The second method described on page 125 of this issue, was approximately ten times more sensitive. In this method competition occurs between dapsone and a horseradish peroxidase dapsone conjugate for binding with antibody absorbed onto the microtitre well. ${ }^{5}$ When this method was applied to the detection of dapsone in finger prick blood from two volunteers after the ingestion of single $100 \mathrm{mg}$ dapsone doses, consistently positive results were obtained for 5-6 days. ${ }^{6}$ Although such a finger prick blood method avoids the complication to the interpretation of urine assays caused by the effects of diuresis, it is likely to be considerably less sensitive since the concentrations of dapsone and its metabolites in the serum are much lower than those in the urine. Such tests are probably also less acceptable to patients. As pointed out by Rook in his letter on page 281, further increases in the sensitivity of these 
enzyme-immunoassays are to be anticipated if the peroxidase substrate used in these investigations, 5-amino-salicylic acid, were replaced by the more recently discovered ABTS reagent (2,2'-azino-di-(3-ethyl benzthiazoline-6-sulphonic acid)). ${ }^{57}$ The combination of 3-(dimethylamino) benzoic acid and 3-methyl-2benzo-thiazolinone hydrazone hydrochloride monohydrate (MBTH) described by Ngo and Lenhoff ${ }^{58}$ might also be investigated.

Improved enzyme immunoassay methods could be used to identify those outpatients whose dapsone compliance was so poor that dapsone urinary concentrations (or dapsone/creatinine ratios to allow for diuresis ${ }^{49}$ ) were less than $1-2 \%$ of those among samples collected from supervised controls receiving daily doses of $100 \mathrm{mg}$ dapsone. Such exceedingly irregular patients, who, as will be seen from Table 2, would be most at risk of relapsing on account of the selection of dapsone-resistant strains of $M$. leprae, could then have their treatment specifically supplemented with acedapsone injections.

\section{Monitoring the ingestion of other antileprosy drugs}

The increasing prevalence of dapsone-resistant strains of $M$. leprae among lepromatous patients that has arisen as a result of past treatment with dapsone monotherapy has emphasized the importance of treating all new lepromatous patients with combinations of antileprosy drugs. The most promising drugs for use in combination with dapsone or for the treatment of patients with dapsoneresistant leprosy are rifampicin, clofazimine, ethionamide, prothionamide and thiacetazone. ${ }^{28}$ The regularity with which such companion drugs are taken is likely to be a major factor in determining their potential value in preventing the emergence of dapsone resistance. An experimental investigation in the mouse foot-pad model has indicated that poor compliance would probably severely impair the efficacy of thiacetazone, since it is an inherently weak bacteriostatic drug, ${ }^{59}$ and would compromise the bactericidal activities of ethionamide and prothionamide. ${ }^{60}$

The taking of a standard $600 \mathrm{mg}$ dose of rifampicin can often be detected simply from the characteristic orange/brown colour that it imparts to urine samples collected within $6-8 \mathrm{~h}$ of ingestion. Rifampicin can, however, be reliably demonstrated in the urine for at least $12 \mathrm{~h}$ using a simple plate diffusion test with Staphylococcus aureus, ${ }^{61}$ while an alternative microbiological procedure of far greater sensitivity has also been described. ${ }^{62}$

No method has as yet been described for monitoring the ingestion of clofazimine. Among light-skinned patients the degree of skin pigmentation may provide an indication of the extent to which the drug is being taken, but it is in just such patients that the clofazimine is likely to be least acceptable. A urinetest method for detecting the ingestion of ethionamide has been described by Eidus and Harnanansingh. ${ }^{63}$ This method, which depends on the extraction and 
concentration of its yellowish sulphoxide metabolite, is also applicable to detecting the ingestion of prothionamide and gives reliably positive results for at least $12 \mathrm{~h}$ after the ingestion of $250 \mathrm{mg}$ doses of either drug. ${ }^{63,64}$

No satisfactory colorimetric procedure exists for monitoring the ingestion of thiacetazone, but its excretion in the urine can be detected by extracting into chloroform/amyl alcohol and scanning the ultraviolet absorption spectrum of the extract to detect an absorption peak at about $333 \mathrm{m \mu} .{ }^{65}$ Reliably positive results may be anticipated for about $36-48 \mathrm{~h}$ after dosage with $150 \mathrm{mg}$ of the drug.

Combined formulations of rifampicin plus isoniazid, ethionamide plus isoniazid, prothionamide plus isoniazid and thiacetazone plus isoniazid are commercially available for use in the treatment of tuberculosis while a combination of dapsone plus prothionamide plus isoniazid has been developed for use with rifampicin in the treatment of both leprosy and tuberculosis. The use of such isoniazid-containing combinations could considerably facilitate compliance studies concerning the ingestion of these drugs since their ingestion can be readily detected using colorimetric procedures to detect the presence of metabolites of isoniazid in the urine.

The Eidus and Hamilton procedure ${ }^{66}$ for detecting acetylisoniazid is extremely simple. Twelve urine samples can be reacted at a time using a white procelain plate with hemispherical depressions with the dropwise addition of aqueous potassium cyanide and chloramine-T. A positive result is indicated by the appearance of a pink/red colour within 5 min. Urine samples collected after a $300 \mathrm{mg}$ dose of isoniazid, the size of the isoniazid component of most of these combined formulations, would give reliably positive results for about $12 \mathrm{~h}$ and be uniformly negative after $48 \mathrm{~h} .64,67,68$

The urine-test method for monitoring isoniazid ingestion based on detecting the metabolites isonicotinic acid and isonicotinylglycine ${ }^{69}$ is slightly more elaborate involving the addition of $\mathrm{pH} 5$ acetate buffer and the reagents potassium cyanide, chloramine-T and barbituric acid. A positive result is indicated by the formation of a blue/purple colour within $15-30 \mathrm{~min}$. This method is much more sensitive than the acetylisoniazid procedure and gives reliably positive results for about $48 \mathrm{~h}$ after the ingestion of $300 \mathrm{mg}$ isoniazid. ${ }^{64}$ Such an approach was used to monitor the self-administration of thiacetazone in the Ethiopian compliance study reported on page 147 .

Such standard therapeutic doses of isoniazid are very well tolerated so that the use of such combined formulations for relatively limited compliance studies poses no unacceptable hazard to the patients. The sensitivity of the isonicotinic acid method for detecting isoniazid ingestion is however so great that it is possible to use minute doses of isoniazid as an innocuous marker for monitoring the self-administration of medicaments for daily self-administration since over $99 \%$ of the urine samples collected within $18 \mathrm{~h}$ of ingesting $6 \mathrm{mg}$ isoniazid gave positive results. ${ }^{70}$ Such doses of isoniazid have been incorporated into capsules 
or tablets containing dapsone, thiacetazone, ethionamide or prothionamide in preparation for future studies concerning the regularity of their selfadministration by leprosy patients.

\section{Supplementing daily self-administered dapsone with supervised intermittent treatment of other drugs}

Just as the demonstration of irregular drug self-administration in the treatment of tuberculosis prompted the introduction of supervised chemotherapy, the evidence of poor dapsone compliance in leprosy illustrated by the investigations summarized in Table 1 has encouraged the advocacy of supplementing oral daily doses of dapsone with injections of $225 \mathrm{mg}$ acedapsone given once every 3 months. ${ }^{47,}{ }^{71-5}$ Such injections, which release on average about $2 \mathrm{mg}$ dapsone into the circulation each day and maintain dapsone serum concentrations in excess of about $0.03 \mu \mathrm{g} / \mathrm{ml},{ }^{76^{-8}}$ would prevent the multiplication of both fully sensitive Mycobacterium leprae and mutants with low degrees of dapsone resistance and would significantly augment the dapsone levels of patients whose compliance as defined above was exceedingly irregular.

In view of the extremely rapid and powerful bactericidal activity of rifampicin against $M$. leprae $e^{79-81}$ and its high cost, the most advantageous way to supplement self-administered daily dapsone treatment would probably be to give single $600 \mathrm{mg}$ doses of the drug once-monthly to outpatients on the occasion of a clinic visit to collect their stock of dapsone tablets. ${ }^{75}$ An additional rifampicin dose could also be given for self-administration on the following day. ${ }^{82}$ Supervised monthly doses of clofazimine might be given in a similar manner. ${ }^{83}$ However experimental studies indicate that ethionamide, prothionamide and thiacetazone are probably unsuitable drugs for intermittent administration. ${ }^{60}$

G A ELLARD

\section{References}

1 Cates CJ. An assessment of dapsone self-administration in Gudiyathan Taluk. Lepr Rev, $1981,52,55-64$.

2 Davies RA, Ng YY. Dapsone compliance in North-East India. Lepr Rev, 1981, 52, 51-3.

${ }^{3}$ Ellard GA, Pearson JMH, Haile GS. The self-administration of dapsone by leprosy patients in Ethiopia. Lepr Rev, 1981, 52, 147-53.

${ }^{4}$ Huikeshoven H, Wit M de, Soeters A, Landheer JE, Leiker DL. ELISA inhibition technique for the demonstration of sulphones in body fluids. II. A new method to monitor leprosy patient compliance under field conditions. Lepr Rev, 1981, 52, 11-18.

5 Wit M de, Huikeshoven H, Soeters A, Eggelte TA, Landheer JE, Leiker DL. ELISA inhibition technique for the demonstration of sulphones in body fluids. Comparison to two ELISA methods. Lepr Rev, 1981, 52, 125-30.

${ }^{6}$ Huikeshoven H, Wit M de, Soeters A, Landheer JE, Leiker DL, Niemer AQHJ, Warndorff T. 
ELISA inhibition technique for the demonstration of sulphones in body fluids. The use of dried blood on filter paper to monitor leprosy patient compliance. Lepr Rev, $1981,52,131-38$.

7 Huikeshoven H, Wit M de, Eggelte TA, Landheer JE, Leiker DL. Hiaemagglutination inhibition technique for the demonstration of sulphones in urine. Lepr Rev, 1981, 52, $139-45$.

8 Fox, W. Self-administration of medicaments. A review of published work and a study of the problems. Bull Int Un Tuberc, 1962, 32, 307-31.

9 Porter AMW. The problem of self-administration of drugs. 1968 M.D. Thesis. University of London.

10 Marston M. Compliance with medical regimens: a review of the literature. Nurs Res, 1970, $19,312-23$.

11 Blackwell B. The drug defaulter. Clin Pharmac Ther, 1972, 13, 841-8.

12 Sackett, DL, Haynes RB. Compliance with therapeutic regimens. 1976. Johns Hopkins University Press, Baltimore and London.

13 Haynes RB, Taylor DW, Sackett DL. (Eds). Compliance in health care. 1979. Johns Hopkins University Press, Baltimore and London.

14 Hong Kong Anti-tuberculosis Association and Government Tuberculosis Service/British Medical Research Council Investigation. A controlled comparison of thiacetazone (thioacetazone) plus isoniazid with PAS plus isoniazid in Hong Kong. Tubercle, 1968, $49,243-80$.

15 East African/British Medical Research Council. Isoniazid with thiacetazone (thioacetazone) in the treatment of pulmonary tuberculosis in East Africa - Fifth investigation. Tubercle, 1970, 51, 123-51.

16 Singapore Tuberculosis Services/Brompton Hospital/British Medical Research Council Investigation. A controlled clinical trial of the role of thiacetazone-containing regimens in the treatment of pulmonary tuberculosis in Singapore. Tubercle, 1971, 52, 88-116.

17 Tuberculosis Chemotherapy Centre, Madras. Controlled comparison of oral twice-weekly and oral daily isoniazid plus PAS in newly diagnosed pulmonary tuberculosis. Brit Med $J, 1973$, ii, 7-11.

${ }^{18}$ Hong Kong Tuberculosis Treatment Services/British Medical Research Council Investigation. A study in Hong Kong to evaluate the role of pretreatment susceptibility tests in the selection of regimens of chemotherapy for pulmonary tuberculosis. Second report. Tubercle, 1974, 55, 169-92.

19 East African/British Medical Research Councils Study. Controlled clinical trial of four short-course regimens of chemotherapy for two durations in the treatment of pulmonary tuberculosis. Amer Rev Resp Dis, 1978, 118, 39-48.

20 Frimodt-M $\phi$ ller J, Parthasarathy R. Preliminary results of domiciliary drug therapy for one year on a community basis. J Christian med Ass India, 1964, 39, 517-24.

${ }^{21}$ Kent PW, Fox W, Miller AB, Nunn AJ, Tall R, Mitchison DA. The therapy of pulmonary tuberculosis in Kenya: A comparison of the results achieved in controlled clinical trials with those achieved by routine treatment services. Tubercle, 1970, 51, 24-38.

22 East African/British Medical Research Council Co-operative Investigation. Tuberculosis in Tanzania: a follow-up of a national sampling survey of drug resistance and other factors. Tubercle, 1977, 58, 55-78.

${ }^{23}$ East African/British Medical Research Council Co-operative Investigation. Tuberculosis in Kenya: Follow-up of the second (1974) national sampling survey and a comparison with the follow-up data from the first (1964) national sampling survey. Tubercle, $1979,60,125-49$.

${ }^{24}$ Fox W, Mitchison DA. Short-course chemotherapy for pulmonary tuberculosis. Amer Rev Resp Dis, 1975, 111, 325-53. 
${ }^{25}$ Fox W. The chemotherapy of pulmonary tuberculosis: A review. Chest, 1979, 76S, $785 \mathrm{~S}-96 \mathrm{~S}$.

26 Mitchison DA. Treatment of tuberculosis. The Mitchell lecture 1979. J Roy Coll Physicians London, 1980, 14, 91-9.

27 Ellard GA. Profile of urinary dapsone/creatinine ratios after oral dosage with dapsone. Lepr Rev, 1980, 51, 229-36.

${ }^{28}$ Colston MJ, Ellard GA, Gammon PT. Drugs for combined therapy: Experimental studies on the antileprosy activity of ethionamide and prothionamide, and a general review. Lepr Rev, 1978, 49, 115-26.

29 Ellard GA, Gammon PT, Helmy HS, Rees RJW. Urine tests to monitor the selfadministration of dapsone by leprosy patients. Amer J Trop Med Hyg, 1974, 23, 464-70.

30 Ellard GA, Gammon PT, Harris JM. The application of urine tests to monitor the regularity of dapsone self-administration. Lepr Rev, 1974, 45, 224-34.

31 Low SJM, Pearson JMH. Do Leprosy patients take dapsone regularly? Lepr Rev, 1974, $45,218-23$.

32 Jesudasan K, George B, Chacko CJG, Taylor PM, Kurian PV, Job CK. An evaluation of the self-administration of DDS in Gudiyatham Taluk. Lepr India, 1976 (Suppl), 48, 668-76.

33 Balakrishnan S. Monitoring self-administration of dapsone by patients. Lepr India, 1977, 49, 364-71.

${ }^{34}$ Hagan KJ, Smith SE, Gyi KM, Lwin MM, Myaing YY, Oo KM, Shwe T, Tin KM, Than KN, Hla T, Kywe WW. The reliability of self-administration of dapsone by leprosy patients in Burma. Lepr Rev, 1979, 50, 201-11.

35 Naik SS. Personal communication 1979.

36 Barton RPE, Rees RJW, McDougall AC, Ellard. GA. The nose in lepromatous leprosy; clinical bacteriological and histopathological studies of patients treated with dapsone monotherapy for various periods of time. In preparation.

${ }^{37}$ Huikeshoven H, Honhoff C, Eys GJJM Van, Anten JGF, Mayer JMA, Helden HPT Van. Weekly self-medication of leprosy patients monitored by DDS/creatinine ratios in urines. Lepr Rev, 1976, 47, $201-9$.

${ }^{38}$ Huikeshoven H, Bijleveld I. Encouraging results from DDS urine analysis among registered leprosy patients in the Wangas, Kenya. An exception that challenges the rule. Lepr $R e v, 1978,49,47-52$.

39 Davey TF. Realism in leprosy control. Lepr Rev, 1974, 45, 197-200.

40 Hertroijs AR. A study of some factors affecting the attendance of patients in a leprosy control scheme. Int J Lepr, 1974, 42, 419-27.

41 Ellard GA, Gammon PT, Rees RJW, Waters MFR. Studies on the determination of the minimal inhibitory concentration of 4,4'-diamino-diphenyl-sulphone (Dapsone, DDS) against Mycobacterium leprae. Lepr Rev, 1971, 42, 101-17.

42 Shepard CC, Levy L, Fasal P. The sensitivity to dapsone (DDS) of Mycobacterium leprae from patients with and without previous treatment. Amer J Trop Med Hyg, 1969, 18, 258-63.

43 Jacobson RR. Sulphone resistant leprosy: Etiology, incidence and treatment in the United States. Int J Lepr, 1973, 41, 684.

44 Pearson JMH, Rees RJW, Waters MFR. Sulphone resistance in leprosy. A review of one hundred proven clinical cases. Lancet, 1975, ii, 69-72.

45 Pearson JMH. Personal communication, 1980.

46 Pearson JMH, Haile GS, Barnetson RSC, Rees RJW. Dapsone-resistant leprosy in Ethiopia. Lepr Rev, 1979, 50, 183-99. 
47 Ellard GA. Pharmacological aspects of the chemotherapy of leprosy. Lepr Rev, 1975, 46 (Suppl.), 41-51.

48 Rees RJW, Ellard GA, Ambrose EJ, Colston MJ, Levy L, Morrison NE, Pattyn SR, Pearson JMH, Peters JH, Shepard CC. Report of the Workshop on Experimental Chemotherapy of the Eleventh International Leprosy Congress. Int J Lepr, 1979, 47 (Supp1.), 297-303.

49 Jenner PJ, Ellard GA. High pressure liquid chromatographic methods for the determination of dapsone and thiacetazone in body fluids and their application to pharmacological studies in man. In preparation.

50 Carr K, Oates JA, Nies AS, Woosley RL. Simultaneous analysis of dapsone and monoacetyldapsone employing high performance liquid chromatography: A rapid method for determination of acetylator phenotype. Brit J Clin Pharmac, 1978, 6, 421-7.

51 Jones CR, Ovenell SM. Determination of plasma concentrations of dapsone, monoacetyldapsone and pyrimethamine in human subjects dosed with maloprim. $J$ Chromatogr, 1979, 163, 179-85.

52 Murray JF, Gordon GR, Gulledge CC, Peters JH. Chromatographic-fluorometric analysis of antileprotic sulfones. J Chromatogr, 1975, 107, 67-72.

53 Ahmed RA, Rogers HJ. Plasma and salivary pharmacokinetics of dapsone estimated by a thin layer chromatographic method. Eur J Clin Pharmacol, 1980, 17, 129-33.

54 Huikeshoven H, Landheer JE, Denderen AC Van, Vlasman M, Leiker DL, Das PK, Goldring OL, Pondman KW. Demonstration of dapsone in urine and serum by ELISA inhibition. Lancet, 1978, i, 280-1.

55 Huikeshoven $\mathrm{H}$, Wit $\mathrm{M}$ de, Soeters A, Eggelte TA, Landheer JE, Leiker DL. ELISA inhibition technique for the demonstration of sulphones in body fluids. I. Sulphones specific antibody-enzyme conjugate. Lepr Rev, 1979, 50, 275-81.

56 Huikeshoven H. Patient compliance with dapsone administration in leprosy. Analytical and pharmaceutical aspects. Thesis, Amsterdam, 1980.

${ }^{57}$ Groom NP. Superiority of ABTS over Trinder reagent as chromogen in highly sensitive peroxidase assays for enzyme linked immunoadsorbent assay. $J$ Clin Chem Clin Biochem, 1980, 18, 345-9.

58 Ngo TT, Lenhoff HM. A sensitive and versatile chromogenic assay for peroxidase and peroxidase-coupled reactions. Analyt Biochem, 1980, 105, 389-97.

59 Colston MJ, Hilson GRF, Ellard GA, Gammon PT, Rees RJW. The activity of thiacetazone, thiambutosine, thiocarlide and sulphamethoxypyridazine against Mycobacterium leprae in mice. Lepr Rev, 1978, 49, 101-13.

60 Colston MJ, Hilson GRF, Lancaster RD. Intermittent chemotherapy of experimental leprosy in mice. Amer J Trop Med Hyg, 1980, 29, 103-8.

61 Mitchison DA, Allen BW, Miller AB. Detection of rifampicin in urine by a simple microbiological assay. Tubercle, 1970, 51, 300-4.

${ }^{62}$ Mitchison DA, Allen BW, Gabriel M, Nunn AJ. Sensitive microbiological method for the detection of rifampicin in urine. Tubercle, 1974, 55, 245-8.

${ }^{63}$ Eidus L, Harnanansingh AM. A urine test for control of ingestion ethionamide. Amer Rev Resp Dis, 1968, 98, 315-16.

64 Ellard GA, Unpublished results.

65 Ellard GA, Dickinson JM, Gammon PT, Mitchison DA. Serum concentrations and antituberculosis activity of thiacetazone. Tubercle, 1974, 55, 41-54.

66 Eidus L, Hamilton EJ. A new method for the determination of $\mathrm{N}$-acetyl-isoniazid in urine of ambulatory patients. Amer Rev Resp Dis, 1964, 89, 587-8.

67 Venkataraman P, Eidus L, Ramachandran K, Tripathy SP. A comparison of various methods for the detection of isoniazid and its metabolites in urine. Tubercle, 1965, 46, 262-9. 
Rao KVN, Eidus L, Jacob CV, Radhakrishna S, Tripathy SP. Sodium nitroprusside test for the detection of isoniazid and acetylisoniazid in urine. Tubercle, 1967, 48, 45-50.

Ellard GA, Greenfield C. A sensitive urine-test method for monitoring the ingestion of isoniazid. J Clin Path, 1977, 30, 84-7.

70 Ellard GA, Jenner PJ, Downs PA. An evaluation of the potential use of isoniazid, acetylisoniazid and isonicotinic acid for monitoring the self-administration of drugs. Brit $J$ Clin Pharmac, 10, 369-81.

71 Shepard CC, Tolentino JS, McRae DH. The therapeutic effect of 4,4'-diacetylaminoDiphenyl sulphone (DADDS). Amer J Trop Med Hyg, 1968, 17, 192-201.

72 Pattyn SR. Comments of the chemotherapy of leprosy as influenced by present knowledge of Mycobacterium leprae. Lepr Rev, 1972, 43, 126-36.

73 Rees RJW. Drugs for leprosy. Tropical Doctor, 1973, 3, 92-5.

74 Ellard GA. The treatment of tuberculosis and leprosy. Lepr Rev, 1975, 46, 149-55.

75 Ellard GA. Combined treatment for lepromatous leprosy. Lepr Rev, 1980, 51, 199-205.

76 Glazko AJ, Dill WA, Montalbo RG, Holmes EL. A new analytical procedure for dapsone. Application of blood-level and urinary-excretion studies in normal men. Amer J Trop Med Hyg, 1968, 17, 465-73.

77 Ozawa T, Shepard CC, Karat ABA. Application of spectrophotofluorometric procedures to some problems in Mycobacterium leprae infections in mice and man treated with dapsone (DDS), diacetyl-DDS (DADDS), and di-formyl-DDS (DFD). Amer J Trop Med Hyg, 1971, 20, 274-81.

78 Peters JH, Murray JF, Gordon GR, Levy L, Russell DA, Scott GC, Vincin DR, Shepard CC. Acedapsone treatment of leprosy patients: response versus drug disposition. Amer $J$ Trop Med Hyg, 1977, 26, 127-36.

79 Shepard CC, Levy L, Fasal P. Rapid bactericidal effect of rifampicin on Mycobacterium leprae. Amer J Trop Hyg, 1972, 21, 446-9.

${ }^{80}$ Shepard CC, Levy L, Fasal P. Further experience with the rapid bactericidal effect of rifampicin on Mycobacterium leprae. Amer J Trop Med Hyg, 1974, 23, 1120-4.

81 Waters MFR, Rees RJW, Pearson JMH, Laing AMG, Helmy HS, Gelber RH. Rifampicin for lepromatous leprosy: nine years' experience. Brit Med J 1978, i, 133-6.

82 Rees RJW. Rifampicin: the investigation of a bactericidal drug. Lepr Rev, 1975, 46 (Suppl.), 121-4.

${ }^{83}$ Collaborative Effort of the U.S. Leprosy Panel and the Leonard Wood Memorial. Spaced clofazimine therapy of lepromatous leprosy. Amer J Trop Med Hyg, 1976, 25, 437-44. 